\title{
Thrombosis Therapy: Focus on Antiplatelet Agents
}

Fang Jing' and Wei Zhang ${ }^{1,2 *}$

${ }^{1}$ Institutes for Advanced Interdisciplinary Research, East China Normal University, Shanghai, China

${ }^{2}$ Shanghai Engineering Research Center of Molecular Therapy and Pharmaceutical Innovation, Shanghai, China

\begin{abstract}
Platelet adhesion, activation and aggregation to the injured vessel wall are crucially involved in the pathogenesis of thrombus formation. Agents in theory thwarting these phases would have significant clinical value. The current antiplatelet drugs used in daily clinical practice include COX-1 inhibitor aspirin, ADP P2Y ${ }_{12}$ receptor antagonist clopidogrel, and the GPIlb-Illa antagonists (abciximab, eptifibatide and tirofiban). However, confined curative ratio along with unforeseen bleeding risk remains a major puzzle of antiplatelet therapy. With advances in understanding of the molecular basis of platelet in thrombosis, newer antiplatelet agents that targets different stage of thrombus formation have been recently developed, mostly including agents targeting platelet adhesion (GPIV, vWF), activation (GPVI, P2Y ${ }_{12}$, TPa, PAR1, phosphodiesterase, cyclooxygenase), and aggregation (GPIlb/llla). In this article, we will review the advantages and limitations of various antiplatelet agents that have been approved by the US Food and Drug Administration (FDA) or under development.
\end{abstract}

Keywords: Platelet; Thrombus formation; Antiplatelet drugs

\section{Introduction}

Thrombosis precipitating cardio-cerebrovascular diseases is the most common cause of morbidity and death. Platelets have a central role in thrombus formation [1]. At the cellular level (Figure 1), thrombosis is initiated by platelets tethering to subendothelial von Willebrand factor (vWF) via the glycoproteinIb (GPIb) [2,3]. GPIbavWF interactions mediates the initial adhesion step of platelets to the extracellular matrix (ECM) at high shear rates $\left(>500 \mathrm{~s}^{-1}\right)$. GPIb $\alpha$ may also contribute to platelet adhesion to the intact vessel wall by interacting with P-selectin exposed on activated endothelial cells. At sites of vascular injury, GPVI-collagen interactions initiate intracellular signaling pathway followed by shifting of integrins to high-affinity state and the release of secondarily acting agonists (ie, ADP, serotonin, and calcium), as well as synthesizing thromboxane from arachidonic acid (AA). At the same time, exposed tissue factor (TF) locally triggers the formation of thrombin (extrinsic pathway). Activation of FXII and FXI also lead to thrombin formation. Platelet activation is subsequently propagated through agonist-receptor interaction, mostly including $\mathrm{ADP}$ via $\mathrm{P} 2 \mathrm{Y}_{1} / \mathrm{P} 2 \mathrm{Y}_{12}$, thrombin via protease-activated receptor 1 (PAR1) and PAR4, and thromboxane via the thromboxane receptor (TP). At the same time, activated platelets act as a catalytic surface for thrombin generation from its plasma pro-enzymes (intrinsic pathway) [4,5]. Finally, the activated platelets co-aggregate with fibrinogen and vWF via GPIIb/IIIa [6,7]. This leads to thrombus stabilization by insoluble fibrin intermeshed within and around the platelet thrombus. The three dimensional platelet plugs under pathophysiological conditions can obstruct circulatory system patency leading to ischemic heart disease (myocardial infarction, unstable angina), ischemic stroke, and related conditions [8]. Antiplatelet therapy is a well-established thrombolytic approach for patients with thromboembolic disorders. In this article, we will review the advantages and limitations of FDA-approved or investigational antiplatelet agents in the treatment of thrombotic events.

\section{Anti-platelet Agents Targeting Platelet Adhesion}

Pharmacological agents targeting vWF or GPIba are a promising antiplatelet strategy. As listed in Table 1, nine these agents are currently under investigation. It includes ARC1779, AJW200, 82D6A3, ARC15105, ALX-0081 and ALX-0681,h6B4-Fab, GPGP-290, SZ2.

\section{Agents Targeting vWF}

ARC1779 (Archemix Corp) is a novel aptamer-based chemical antibody that binds to vWF A1 domain with high affinity and little immunogenicity $[9,10]$. In vitro, ARC1779 inhibits vWF A1-dependent or shear stress-induced platelet aggregation as well as platelet adhesion to collagen-coated matrices [11]. In vivo, injection of ARC1779 leads to reduced thrombus formation on porcine arteries, and delayed carotid artery thrombosis in primates [11]. Incubation of ARC1779 with platelets from coronary artery disease (CAD) patients impaired shear stress-induced platelet adhesion [12]. A Phase II clinical trial showed that continuing injection of ARC1779 may prevent platelet aggregation and increase platelet counts in thrombotic thrombocytopenic purpura patients [13].

AJW200 is a humanized monoclonal antibody (mAb) against vWF A1 domain. In vitro, AJW200 inhibits high-shear-stress-induced human platelet aggregation in a dose-dependent manner [14]. A further clinical trial to verify its safety and efficacy is still ongoing.

Other vWF antagonists including 82D6A3, ARC15105, ALX0081, and ALX-0681 are still in preclinical or clinical studies. 82D6A3 is a $\mathrm{mAb}$ against vWF A3 domain [15]. Preclinical study showed that 82D6A3 completely inhibited the binding between vWF and collagen in baboon stent implantation [16]. ARC15105 is a chemically advanced aptamer. Ex vivo trials demonstrated it had less inhibition effect on platelet aggregation than ARC1779 [17]. ALX-0081 and ALX-0681 are humanized nanobody against vWF A1 domain which inhibits binding of vWF to GP Ib. Currently, Phase II clinical study of ALX-0081 in percutaneous coronary intervention (PCI) patients is ongoing [18].

*Corresponding author: Wei Zhang, Shanghai Engineering Research Center of Molecular Therapy and Pharmaceutical Innovation, North Zhongshan Road, Shanghai, China, Tel: +86 21 32530498; Fax: +86 21 32530498; E-mail: wzhang@sat.ecnu.edu.cn

Received June 03, 2013; Accepted July 10, 2013; Published July 15, 2013

Citation: Jing F, Zhang W (2013) Thrombosis Therapy: Focus on Antiplatelet Agents. Int J Genomic Med 1: 103. doi:10.4172/2332-0672.1000103

Copyright: (c) 2013 Jing F, et al. This is an open-access article distributed under the terms of the Creative Commons Attribution License, which permits unrestricted use, distribution, and reproduction in any medium, provided the original author and source are credited. 


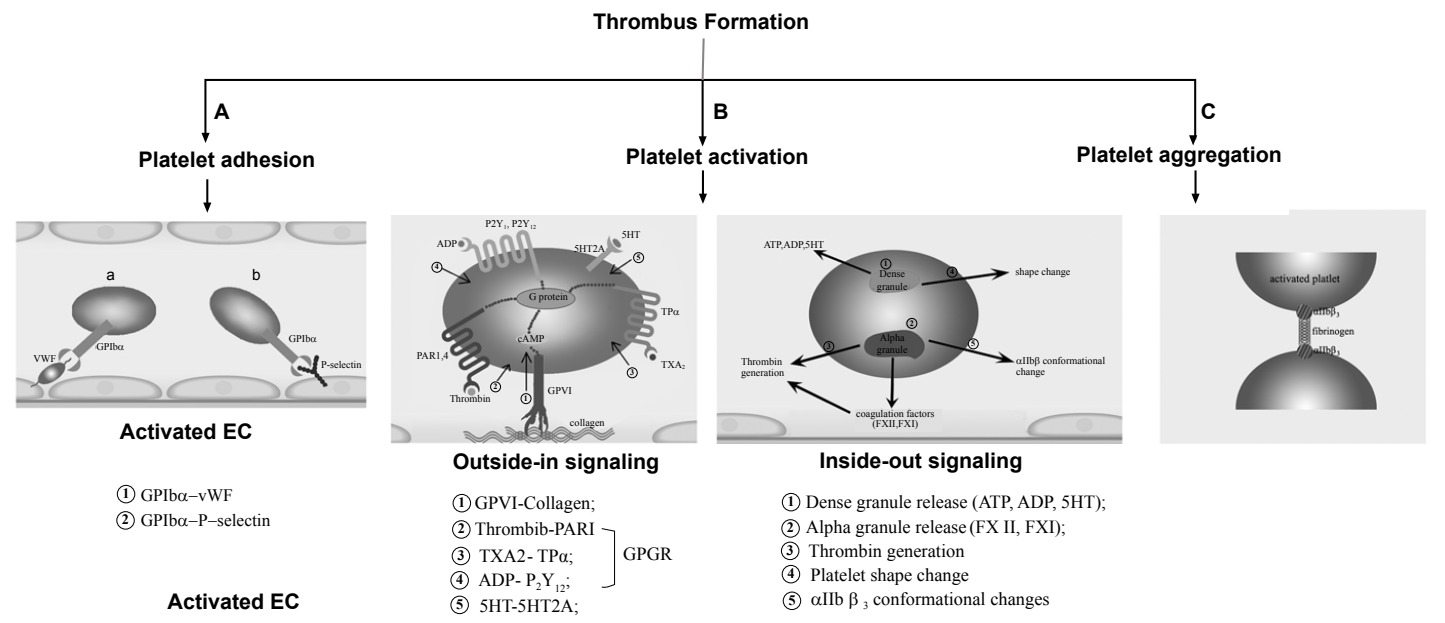

Figure 1: Molecular mechanisms of thrombus formation showing the key site of action of antiplatelet drugs. Events occur following (A) platelet adhesion; (B) activation; (C) aggregation. GP, glycoprotein; vWF, von Willebrand Factor; PAR, protease-activated receptor; TXA2, thromboxane; TP, thromboxane/prostanoid receptor; ADP, adenosine diphosphate; GPGR, G-protein-coupled-receptor; 5HT, 5-hydroxytryptamine.

\begin{tabular}{|c|c|c|c|c|}
\hline Agent & Type & Target & Mechanism of action \\
\hline ARC1779 & $\begin{array}{c}\text { aptamer-based chemical } \\
\text { antibody }\end{array}$ & vWF & Aptamer against vWF A1 domain; inhibits binding of vWF to GPIb \\
\hline AJW200 & Humanized mAb & vWF & mAb against vWF A1 domain; inhibits binding of vWF to GPIb \\
\hline 82D6A3 & mAb & vWF & mAb against vWF A3 domain; inhibits binding of vWF to collagen \\
\hline ARC15105 & Chemically advanced aptamer & vWF & assumed higher affinity to vWF \\
\hline ALX-0081 & Nanobody & vWF & Nanobody against vWF A1 domain; Inhibits binding of vWF to GP Ib \\
\hline ALX-0681 & Nanobody & vWF & Nanobody against vWF A1 domain; Inhibits binding of vWF to GP Ib \\
\hline h6B4-Fab & humanized Fab fragment & GPIba & Fab fragment against GPIba and neutralizes the binding sites of vWF to GPIba \\
\hline GPGP-290 & $\begin{array}{c}\text { chimeric recombinant protein } \\
\text { from CHO cell culture }\end{array}$ & GPIba & Preclinical \\
\hline SZ2 & contains the N-terminal 290 aa of GPIba linked to the human IgG1 \\
\hline
\end{tabular}

mAb, monoclonal antibody; GP lb, Glycoprotein Ib; vWF, von Willebrand factor; CHO,Chinese hamster ovary cell.

Table 1: Agents targeting platelet adhesion.

\section{Agents Targeting GPIb Receptor}

The h6B4 is a fully recombinant and humanized Fab fragment against GPIba [19]. It inhibits platelet adhesion by competing with vWF for binding to GPIba under high-shear condition. In vivo in baboons, thrombus formation was induced at an injured and stenosed site of the femoral artery, resulting in cyclic flow reduction (CFRs). Injection of h6B4-Fab dose-dependently reduced the CFRs without significant increase in bleeding time. This antibody is a useful tool to study the role of GPIb in human thrombotic diseases.

GPG 290 is a chimeric recombinant protein from Chinese hamster ovary $(\mathrm{CHO})$ cell culture that contains the amino-terminal 290 amino acid of GPIba linked to the human IgG1. Preliminary data show GPG 290 has prolonged bleeding time in vivo in dogs; despite it provides protection against coronary artery thrombosis [20].

$\mathrm{SZ2}$ is a mAb against GPIba. In vitro, it inhibits both ristocetinand botrocetin-induced platelet aggregations [21]. The in vivo efficacy of SZ2 is still under investigation.

\section{Anti-platelet Agents Targeting Platelet Activation}

Agents targeting platelet receptors and signaling molecules are the potential therapeutic targets. As listed in Table 2, seven of these agents have been approved by FDA, and thirteen of these agents are currently under investigation.

\section{Agents Targeting GPVI Receptor}

PR-15 (Revacept; ABX-CRO/Medifacts) is a dimeric glycoprotein (GPVI)-Fc. PR-15 has been reported to inhibit collagen-induced platelet adhesion without affecting general hemostasis in humans $[22,23]$, and abolished platelets stable arrest and aggregation following vessel injury in mice [24]. A Phase I clinical trial demonstrated that PR15 injection was safe and capable of suffering by healthy subjects [25].

DZ-697b is a newer orally antiplatelet agent that inhibits collagenor ristocetin-induced platelet activation. Although further clinical investigation of DZ-697b is still ongoing, Phase I study demonstrated patients treated with DZ-697b had reduced bleeding events compared with $\mathrm{P} 2 \mathrm{Y}_{12}$ antagonist clopidogrel treatment [26].

\section{Agents Targeting ADP Receptor}

Adenosine diphosphate (ADP), an important platelet agonist in vivo, has two types of membrane receptors named $\mathrm{P} 2 \mathrm{Y}_{1}$ and $\mathrm{P} 2 \mathrm{Y}_{12}$ [27]. $\mathrm{P}_{2} \mathrm{Y}_{1}$ is a $\mathrm{Gq}$ linked 7-transmembrane G-protein-coupled-receptor (GPCR), while P2Y $\mathrm{Y}_{12}$ is coupled to Gi protein. Activation of the P2Y receptor leads to calcium mobilization, a rapid platelet shape change and reversible aggregation. However, activation of $\mathrm{P}_{2} \mathrm{Y}_{12}$ allows for a 


\begin{tabular}{|c|c|c|c|c|c|c|c|}
\hline Agent & Type & Target & $\begin{array}{l}\text { Mechanism of } \\
\text { action }\end{array}$ & Half -life & Administration & Stage & Use and side effect \\
\hline $\begin{array}{c}\text { Ticlopidine } \\
\text { (Ticlid; Roche) }\end{array}$ & Thienopyridine & $\mathrm{P}_{2} \mathrm{Y}_{12}$ & $\begin{array}{l}\text { Active metabolite } \\
\text { irreversibly inhibits } \\
\text { P2Y12 receptor }\end{array}$ & 12 hours & Oral; Twice daily & FDA-approved; & $\begin{array}{c}\text { Transient ischemic attacks, patients } \\
\text { undergoing PCl; } \\
\text { Bleeding; Gastrointestinal toxicity; } \\
\text { heartburn, indigestion, nausea and } \\
\text { moving; Rash; Neutropenia, TTP(rare) }\end{array}$ \\
\hline $\begin{array}{l}\text { Clopidogrel } \\
\text { (Plavix; Bristol- } \\
\text { Myers Squibb/ } \\
\text { Sanofi-Ave) }\end{array}$ & Thienopyridine & $P_{2} Y_{12}$ & same as Ticlopidine & $\begin{array}{c}6-8 \\
\text { hours }\end{array}$ & Oral; Daily & $\begin{array}{l}\text { FDA-approved; } \\
\text { (Patient -to-patient } \\
\text { variability) }\end{array}$ & $\begin{array}{l}\text { NSTEMI,STEMI,PCI, recent stroke, or } \\
\text { established PAD; } \\
\text { Bleeding, Rash, Neutropenia, TTP(rare) }\end{array}$ \\
\hline $\begin{array}{l}\text { Prasugrel } \\
\text { (Effient; Eli Lilly/ } \\
\text { Daiichi Sankyo) }\end{array}$ & Thienopyridine & $\mathrm{P}_{2} \mathrm{Y}_{12}$ & same as Ticlopidine & 8 hours & Oral; Daily & FDA-approved & $\begin{array}{c}\text { Patients with ACS undergoing PCI } \\
\text {-more bleeding risk and greater cost than } \\
\text { clopidogrel } \\
\text {-Stop in patients with a history of stroke } \\
\text { or (TIA) } \\
\text { - Not recommended in patients }>75 \text { years } \\
\text { old unless they are at high risk of CAD } \\
\text { events }\end{array}$ \\
\hline $\begin{array}{l}\text { Tricagrelor } \\
\text { (AZD6140; } \\
\text { AstraZeneca) }\end{array}$ & Thienopyridine & $P_{2} Y_{12}$ & same as Ticlopidine & $\begin{array}{c}6-12 \\
\text { hours }\end{array}$ & Oral; - & FDA-approved & STEMI, ACS \\
\hline Aspirin & $\begin{array}{l}\text { Acetylsaicylic } \\
\text { acid }\end{array}$ & $\operatorname{cox} 1$ & $\begin{array}{c}\text { Irreversible } \\
\text { acetylation of serine } \\
529 \text { of COX1 }\end{array}$ & - & Oral; Daily & $\begin{array}{l}\text { FDA-approved } \\
\text { (Weak antiplatelet } \\
\text { agent) }\end{array}$ & $\begin{array}{c}\text { CVDs and Stroke; } \\
\text { Bleeding, Gastrointestinal toxicity: } \\
\text { heartburn, indigestion, nausea, vomiting, } \\
\text { gastric ulceration }\end{array}$ \\
\hline $\begin{array}{l}\text { Dipyridamole } \\
\text { (Boehringer } \\
\text { Ingelheim) }\end{array}$ & $\begin{array}{c}\text { Pyrimidopyridine } \\
\text { derivative }\end{array}$ & $\begin{array}{l}\text { PDE and } \\
\text { inhibition of } \\
\text { adenosine } \\
\text { uptake }\end{array}$ & $\begin{array}{c}\text { Antiplatelet and } \\
\text { vasodilatory effects } \\
\text { via inhibition of } \\
\text { cyclic nucleotide } \\
\text { phosphodiesterabe } \\
\text { and of adenosine } \\
\text { uptake }\end{array}$ & 10 hours & $\begin{array}{c}\text { Oral; } 2 \text { or } 3 \text { times } \\
\text { daily }\end{array}$ & $\begin{array}{l}\text { FDA-approved } \\
\text { (Benefit is } \\
\text { most evident in } \\
\text { combination with } \\
\text { low-dose aspirin) }\end{array}$ & $\begin{array}{l}\text { Transient ischemic attacks; } \\
\text { Bleeding, headache, diarrhea, } \\
\text { palpitations, dizziness, rash, } \\
\text { pancytopenia }\end{array}$ \\
\hline $\begin{array}{c}\text { Cilostazol } \\
\text { (Pletal; Otsuka) }\end{array}$ & $\begin{array}{l}\text { 2-Oxoquinoline } \\
\text { derivative }\end{array}$ & PDE3 & $\begin{array}{c}\text { Antiplatelet and } \\
\text { Vasodilatory effects } \\
\text { through inhibition } \\
\text { of cyclic nucleotide } \\
\text { PDE3 }\end{array}$ & $\begin{array}{l}11-13 \\
\text { hours }\end{array}$ & Oral; Twice daily & $\begin{array}{c}\text { FDA-approved } \\
\text { (Side effects leads } \\
\text { to discontinuation of } \\
\text { the drug in } 159 \text { of } \\
\text { patients) }\end{array}$ & $\begin{array}{c}\text { Intermittent claudication, PAD, PCl; } \\
\text { Headache, dizziness, diarrhea, flushing, } \\
\text { hypotension, Vomiting, nausea, } \\
\text { abdomipal pain }\end{array}$ \\
\hline
\end{tabular}

$\mathrm{PCI}$, percutaneous coronary intervention; TTP, thrombotic thrombocytopenic purpura; NSTEMI, non-ST elevation myocardial infarction; ACS, acute coronary syndromes; PAD, peripheral artery disease; TIA, transient ischemic attack; CAD, coronary artery disease; CVD, cardiovascular disease

\section{Table 2.1: Approved agents.}

slow yet progressive platelet aggregation and secretion. Currently, four P2Y 12 antagonists (Ticlopidine, Clopidogrel, Prasugrel, and Ticagrelor) have been approved by FDA, and three of these agents (Elinogrel, Cangrelor and BX667) are under development.

Ticlopidine (Ticlid; Roche), metabolized by cytochrome P450 in the liver, is a first-generation discovered thienopyridine class that irreversibly antagonizes $\mathrm{P} 2 \mathrm{Y}_{12}$ by an active metabolite rather than the parent molecule $[27,28]$. In clinical practice, ticlopidine has been largely substituted by clopidogrel, owing to its delayed onset and obvious hematologic side effects, including neutropenia and thrombotic thrombocytopenic purpura (TTP) [29,30].

Clopidogrel (Plavix; sanofi Aventis/Bristol-Myers Squibb) is a second-generation discovered oral thienopyridine class that requires cytochrome P450 metabolism prior to irreversibly inhibit ADPinduced platelet aggregation by blocking $\mathrm{P}_{12} \mathrm{Y}_{12}$ receptors [27,28]. Currently, clopidogrel has become a standard part of dual antiplatelet therapy with aspirin in patients with acute coronary syndromes (ACS), unstable angina, non-ST elevation myocardial infarction, or stroke [31]; however, the dual regimen was associated with an increased bleeding risk compared with placebo [32]. Moreover clopidogrel has modest platelet inhibition, delayed onset of action, and significant inter-individual variability [33,34]. These shortages appeal to more potent and stable drugs.

Prasugrel (Effient; Eli Lilly/Daiichi Sankyo) is a third-generation discovered thienopyridine class, which irreversibly inhibits the $\mathrm{P}_{12} \mathrm{Y}_{12}$ platelet receptor. It has an approximately 10 -fold greater in vivo potency than clopidogrel [35]. Subjects who responded weakly to clopidogrel demonstrated better platelet-induced inhibition in response to prasugrel [36]. More importantly, TRITON-TIMI 38 (Trial to Assess Improvement in Therapeutic Outcomes by Optimizing Platelet Inhibition with Prasugrel-Thrombolysis in Myocardial Infarction 38), a Phase III trial, demonstrated prasugrel significantly reduced incidences of cardiovascular death and stent thrombosis [37]. However, administration of Prasugrel increases bleeding risk, including fatal bleeding [38]. It is contraindicated in patients with a history of stroke or transient ischemic attacks.

Ticagrelor (a non-thienopyridine) (AZD6140; AstraZeneca) is a direct rather than requiring cytochrome P-450 biotransformation, reversible, and orally active $\mathrm{P}_{2} \mathrm{Y}_{12}$ antagonist with a rapid onset of action, reversible binding, and a low affinity for the $\mathrm{P} 2 \mathrm{Y}_{12}$ receptor [39]. The PLATO (Platelet inhibition and patient Outcomes) trail showed that ticagrelor was superior to clopidogrel in reducing the primary endpoints (a composite of death from vascular causes, myocardial infarction, or stroke) in ACS patients with or without ST-segment elevation [40-42]. However, in subjects enrolled in United States and Canada, ticagrelor showed no benefit compared with clopidogrel. The most common sides of ticagrelor are dyspnea and various nonfatal bleeding such as hematoma, nosebleed, gastrointestinal or dermal bleeding [42]. 


\begin{tabular}{|c|c|c|c|c|c|c|c|}
\hline Agent & Type & Target & Mechanism of action & Half -life & Administration & Stage & Use and side effect \\
\hline PR-15 (Reracept) & Dimeric GPVI-Fc & GPVI & $\begin{array}{l}\text { Inhibits binding to platelet GPVI } \\
\text { receptor }\end{array}$ & - & IV & Phase I completed & - \\
\hline DZ-6976 & - & GPVI & collagen and ristocetin inhibitor & - & Oral & Phase I completed & - \\
\hline $\begin{array}{c}\text { Elinogrel } \\
\text { (PRT060128; } \\
\text { Novartis) }\end{array}$ & Thienopyridine & P2Y12 & same as Ticlopidine & - & Oral or IV; - & Phase II & - \\
\hline $\begin{array}{l}\text { Cangrelor (The } \\
\text { Medicines } \\
\text { Company) }\end{array}$ & Thienopyridine & P2Y12 & same as Ticlopidine & - & $\mathrm{IV} ;-$ & Phase III & - \\
\hline BX667 & - & P2Y12 & same as Ticlopidine & - & Oral & Preclinical & - \\
\hline $\begin{array}{c}\text { S18886 } \\
\text { (Terutroban) }\end{array}$ & - & $\mathrm{TPa}$ & Antagonist of TPa & - & Oral & Phase III & - \\
\hline Z-335 & - & $\mathrm{TPa}$ & Antagonist of TPa & - & Oral & Phase I & - \\
\hline BM-573 & - & $\mathrm{TPa}$ & Antagonist of TPa & - & - & Preclinical & - \\
\hline DG-041 & - & PGE2 & $\begin{array}{c}\text { Inhibits binding to PGE2 receptor } \\
\text { EP3 }\end{array}$ & - & - & Phase II & - \\
\hline $\begin{array}{c}\text { Vorapaxar (SCH } \\
530348)\end{array}$ & $\begin{array}{l}\text { Tricyclic 3-phenylpyridine } \\
\text { analog of himbacine }\end{array}$ & PAR1 & Reversible inhibition of PAR1 & - & Oral; daily & Phase III & - \\
\hline Atopaxar (E5555) & $\begin{array}{l}\text { 2-Iminopyrrolidine } \\
\text { antagonist }\end{array}$ & PAR1 & Reversible inhibition of PAR1 & - & Oral; daily & Phase II & - \\
\hline $\mathrm{SCH} 205831$ & - & PAR1 & Reversible inhibition of PAR1 & - & - & Preclinical & - \\
\hline SCH602539 & - & PAR1 & Reversible inhibition of PAR1 & - & - & Preclinical & - \\
\hline
\end{tabular}

COX1, cyclooxygenase1; PEG, prostaglandin; TPa, Thromboxane receptor $\alpha$; PAR, protease-activated receptor 1.

Table 2.2: Under development.

Elinogrel (PRT060128; Novartis) is a reversible P2Y ${ }_{12}$ antagonist with a direct action and novel structure [27]. A Phase II Clinical trial (patients Undergoing Non-urgent Percutaneous Coronary Interventions, INNOVATE-PCI) showed that elinogrel administered orally or intravenously overcomes high platelet reactivity in patients undergoing PCI who had a weak response to clopidogrel [43]. It is currently in the planning stage of Phase III trial as a next generation $\mathrm{P} 2 \mathrm{Y}_{12}$ antagonist.

Cangrelor (analog of adenosine triphosphate) (The Medicines Company) is an intravenous reversible $\mathrm{P}_{2} \mathrm{Y}_{12}$ antagonist with direct action. Unlike the other $\mathrm{P} 2 \mathrm{Y}_{12}$ antagonists discussed above, cangrelor is a stable analogue of adenosine triphosphate (ATP) administered parenterally, which results in a more rapid onset of action and greater degree of platelet inhibition than clopidogrel. However, Phase II (A Clinical Trial Comparing Cangrelor to Clopidogrel in Subjects who Requires PCI, CHAMPION-PCI) and Phase III (CHAMPIONPLATFORM) trials have been stopped recently due to its limited efficacy in reducing the primary endpoints in PCI patients and higher bleeding risk compared with clopidogrel $[44,45]$.

BX667 is an orally active reversible $\mathrm{P}_{2} \mathrm{Y}_{12}$ antagonist which inhibited ADP-induced platelet aggregation in vitro [46]. In vivo in rat arteriovenous-shunt model [47], oral BX667 administration results in a rapid and lasting thrombus inhibition. It has yet to be assessed in human volunteers.

\section{Agents Targeting Thromboxane $\mathrm{A}_{2} /$ Prostaglandin $\mathrm{H}_{2}$ (TH) Receptor}

Activation of platelet triggers cyclooxygenase 1 (COX-1) induced arachidonic acid (AA) metabolism, resulting in the conversion of AA to prostaglandin $\mathrm{G}_{2} / \mathrm{H}_{2}$, and the latter is subsequently converted to TXA $_{2}$, which is potent platelet activator [48]. Thromboxane receptor $\alpha(\mathrm{TP} \alpha)$, also known as the TH receptor, is a GPCR that coupled to Gq and $G_{12 / 13}$. Binding of TPa with its agonist TXA may result in platelet activation via a number of intracellular pathways which enhances primary platelet activation through thrombin or collagen [49]. TPa has been an attractive target for antiplatelet therapy.

Aspirin, the most widely-used antiplatelet agent, irreversibly inhibits platelet COX-1 activity, leading to reduced synthesis of prostaglandin and $\mathrm{TXA}_{2}$. Long-term aspirin therapy brings about a 20\%-25\% reduction in the odds of subsequent MI, stroke, or vascular death among intermediate- or high-risk cardiovascular diseases (CVDs) patients [50]. However, some patients produce resistance to aspirin because it produces only a partial inhibition of platelet aggregation. Moreover, its gastrointestinal toxicity prompts the search for more specific agents.

S18886 (terutroban) is a novel oral TPa antagonist [51]. In preclinical studies, S18886 rapidly inhibits platelet-dependent thrombosis in vivo in dog, as well as platelet aggregation and stent-induced thrombosis ex vivo [52,53]. However, it had no effect on the myocardial infarct size in ischemia-perfusion model. A phase II study in patients with peripheral artery disease showed that orally administration of S18886 resulted in a rapid inhibition of platelet aggregation without significant adverse events [54]. In the ongoing Phase III clinical trial, Prevention of Cerebrovascular and Cardiovascular Events of Ischemic Origin with Terutroban in Patients with a History of Ischemic Stroke or Transient Ischemic Attack (PERFORM), S18886 and aspirin had similar rates of protection without safety advantages for S18886 [55].

$\mathrm{Z}-335$ is an oral $\mathrm{TPa}$ antagonist that is under investigation [56]. Preclinical data show Z-335 inhibited U46619-induced human platelet aggregation within 2 hours of administration [57].

BM-573 is another exploratory TP $\alpha$ antagonist. Preclinical data demonstrated BM-573 prevented the progression of atherosclerosis in low-density lipoprotein receptor deficient mice [58]. Moreover, BM-573 inhibited AA-induced platelet aggregation [59]. The clinical studies of BM-573 are currently ongoing.

DG-041 is a novel, selective and potent antagonist of prostaglandin $\mathrm{E}_{2}$ (PGE2) receptor subtype3 $\left(\mathrm{EP}_{3}\right)$. Preclinical study showed that 
DG-041 inhibited platelet aggregation by selectively blocking $\mathrm{EP}_{3}$ stimulation [60]. DG-041 is still effective in the presence of a P2Y antagonist and aspirin [61]. It is currently being evaluated in Phase II clinical trials as a potential agent for the treatment of atherothrombosis.

\section{Agents Targeting Phosphodiesterase (PDE) Inhibitor}

PDE isoenzymes from platelet extracts can regulate the metabolism of 3,5'-cyclic adenosine monophosphate (cAMP) and 3',5'-cyclic guanosine monophosphate (cGMP) [62] Elevated cytosol cAMP and cGMP level in the platelet may stimulate signaling pathways that inhibit platelet activation [63]. Currently, two PDE inhibitors (dipyridamole and cilostazol) have been approved by FDA.

Dipyridamole (Aggrenox; Boehringer Ingelheim) a derivant of pyridopyrimidine, has both antiplatelet and vasodilator properties [64]. Its antiplatelet mechanism includes inhibition of cyclic PDE and blockade of adenosine uptake that results in increased intraplatelet cyclic adenosine monophosphate, thereby inhibiting signal transduction. In European Stroke Prevention Study 2 (ESPS-2) and European Stroke Prevention Reversible Ischemia (ESPRIT) trials, dual treatment of dipyridamole and aspirin reduced risk of stroke or death by $37 \%$ compared with aspirin alone [65]. However, it was not superior to clopidogrel in the treatment of recurrent stroke in the Prevention Regimen for Effectively Avoiding Second Strokes (PRoFESS) trial [66].

Cilostazol (Pletal; Otsuka) is an oral selective PDE3 inhibitor with antiplatelet, vasodilatory, and antimitogenic effects [8]. Cilostazol dilates blood vessels and hinders ADP-, collagen- and AA- induced platelet aggregation. It is currently used in the treatment of peripheral ischemia (e.g., intermittent claudication). Like aspirin and clopidogrel, cilostazol is safe and effective in reducing the risk of restenosis and repeated revascularization after PCI; however, a combination of cilostazol with aspirin and clopidogrel do not show superiority in reducing the primary composite endpoints of adverse cardiovascular events after drug-elution stent implantation [67].

\section{Agents Targeting Thrombin Receptor}

Thrombin is the most potent known platelet activator. Protease activated receptor 1 (PAR1) is the major human platelet receptor through which thrombin facilitates cellular effects of platelet activation without interfering with thrombin-induced cleavage of fibrinogen [68]. Currently, two of these agents (vorapaxar, atopaxar) are in Phase II or Phase III investigation.

Vorapaxar (SCH 530348; Schering-Plough), an analog of himbacine, is an orally active, high-affinity reversible PAR1 antagonist. The Thrombin Receptor Antagonist-Percutaneous Coronary Intervention (TRA-PCI) study showed that addition of SCH 530348 to conventional antiplatelet therapy with aspirin and clopidogrel had no significant increase in thrombolysis in MI (TIMI) or bleeding time.
However, the Phase III trials (The Thrombin Receptor Antagonist for Clinical Events Reduction, TRACER; and The Thrombin Receptor Antagonist in Secondary Prevention of Atherothrombotic Ischemic Events, TRA2P-TIMI50) failed because of unforeseen intracranial bleeding [69].

Atopaxar (E5555; Eisai) is an orally administration of the PAR1 antagonist. In preclinical studies, atopaxar inhibits thrombin-mediated platelet aggregation without siginificant bleeding risks [70]. The Phase II trial, performed in patients with coronary artery disease or non-STsegment elevation acute coronary syndrome (NSTE-ACS), supports the efficacy of atopaxar. However, higher incidence of bleeding complications and the lack of a definite dose-related trend for bleeding risk and efficacy should be alert [71-73].

Currently, newer PAR-1 antagonists (e.g. SCH 205831 and SCH 602539) are still under investigation. Preclinical data show SCH 205831 inhibited platelet deposition in arteriovenous-shunt thrombosis model in baboons, and SCH 602539 dose-dependently inhibited thrombus formation in the Folts model of thrombosis in anesthetized cynomolgus monkeys [74].

\section{Anti-platelet Agents Targeting Platelet Aggregation}

The aggregation of platelet and formation of a thrombus requires functional integrin $\alpha \mathrm{IIb} \beta 3$ (GPIIb/IIIa). As a final pathway of platelet activation, it has been a favored target for anti-platelet therapies [68]. As listed in Table 3, there are three FDA-approved GPIIbIIIa antagonists (abciximab, eptifibatide, and tirofiban) and one investigational agent (Z4A5).

Abciximab (ReoPro; Lilly) is an anti- $\alpha \operatorname{IIb} \beta 3$ monoclonal $F(a b ')_{2}$ fragment which developed from the murine human chimera c7E3 Fab, preventing integrin binding to fibrinogen and vWF [75]. Abciximab cross-reacts with the $\alpha v \beta 3$ integrin on endothelial cells and smooth muscle cells and with the $\alpha \mathrm{M} \beta 2$ integrin (CD11b/CD18) on granulocytes and monocytes [76], which is administered intravenously and is beneficial in preventing thrombosis in patients undergoing PCI including percutaneous transluminal angioplastry (PTA), atherectomy and carotid artery stenting (CAS) [77]. The dose required for antithrombotic effects is associated with bleeding risks [78].

Eptifibatide (Integrilin; Millennium Pharmaceuticals/ScheringPlough) is a cyclic heptapeptide that contains a KGD (lysineglycine-aspartic acid) sequence as the active group which selectively recognizes $\alpha \mathrm{II} \beta 3$ and reversibly inhibits platelet aggregation. The Imaging for Myocardial Perfusion Assessment in Coronary artery disease (IMPACT-II) study showed that a single loading dose followed by continuous infusion for 20-24 hours only resulted in $50 \%$ $\alpha \operatorname{IIb} \beta 3$ receptor blockade; thus, limited benefits and efficacy through eptifibatide were observed [79]. Acute Catheterization and Urgent

\begin{tabular}{|c|c|c|c|c|c|c|}
\hline FDA-approved Agent & Type & Target & Mechanism of action & Half-life & Administration & Use and side effect \\
\hline Abciximab (ReoPro; Lilly) & $\begin{array}{c}\text { Murine human } \\
\text { chimeric Fab fragment }\end{array}$ & GP II b- III a & $\begin{array}{l}\text { Preventing integrin } \\
\text { binding to fibrinogen } \\
\text { and vWF }\end{array}$ & $<10-30$ minutes & IV only; Once & $\begin{array}{l}\text { PCl; Bleeding, thrombocytopenia, } \\
\text { EDTA-induced psuedothrombo- } \\
\text { cytopenia }\end{array}$ \\
\hline $\begin{array}{l}\text { Eptifibatide (Integrilin; } \\
\text { Millennium Pharmaceuticals/ } \\
\text { Shering-Plough) }\end{array}$ & $\begin{array}{l}\text { KGD-containing cyclic } \\
\text { heptapeptide }\end{array}$ & GP II b- III a & $\begin{array}{l}\text { Selectively recognizes } \\
\text { integrin GP II b- III a } \\
\text { and reversibly inhibits } \\
\text { platelet aggregation }\end{array}$ & $\sim 2.5$ hours & IV only; Once & $\begin{array}{l}\text { NSTEMI, PCI, Unstable angina; } \\
\text { Bleeding, thrombocytopenia, EDTA- } \\
\text { induced psuedothrombo- cytopenia }\end{array}$ \\
\hline Tirofiban (Aggrastat; Merck) & $\begin{array}{l}\text { Non-peptide mimetic } \\
\text { based on RGD }\end{array}$ & GP II b- III a & $\begin{array}{l}\text { Competitively binds to } \\
\text { intergrin GP II b- III a }\end{array}$ & 2 hours & IV only; Once & Same as Eptifibatide \\
\hline Z4A5 (Preclinical) & & GP $\|b-\| \| a$ & - & - & - & - \\
\hline
\end{tabular}

Table 3: Agents targeting platelet aggregation. 
Intervention Triage strategy (ACUITY) trial showed an increase incidence of major bleeding in patients with ACS undergoing PCI [80].

Tirofiban (Aggrastat; Merck) is a tyrosine-derivative nonpeptide mimetic reversible inhibitor of $\alpha \operatorname{IIb} \beta 3$ that specifically and competitively binds to the receptor with the features of short half-life period, no antigenicity and little adverse reaction. Treatment with tirofiban in combination with aspirin and heparin in patients with ACS significantly reduced the 30-day post-treatment incidence of death, MI, or recurrent ischemia [81]. Like epitifibatide, tirofiban has a common feature of bleeding complications thus unsuitable for prophylaxis [82].

Z4A5 is a novel $\alpha \mathrm{IIb} \beta 3$ peptide antagonist. In the rabbit arteriovenous shunt thrombosis model, Z4A5 demonstrated effective antithrombotic effect when administered with aspirin [83]. Its effect in human subjects is currently under investigation.

\section{Conclusion}

Platelets play a central role in the pathogenesis of thrombosis, antiplatelet therapy is therefore crucial for patients with thrombotic disorders (e.g. ACS or stroke). The current antiplatelet drugs (e.g. the COX-1 inhibitor aspirin, the $\mathrm{P}_{2} \mathrm{Y}_{12}$ receptor antagonist clopidogrel and GPIIb/IIIa antagonists) and the newer agents under development demonstrate definite protection against thrombotic events.

Each category of antiplatelet agents has their advantages and limitations. COX-1 inhibitor aspirin and the $\mathrm{P} 2 \mathrm{Y}_{12}$ receptor antagonist clopidogrel have been used as gold standards in the prevention of arterial thrombotic events; however, unforeseen bleeding risk, limited efficacy, significant inter-individual variability in response and extended duration of action that cannot be reversed in emergency surgery are still the main limitation of these agents. Novel $\mathrm{P} 2 \mathrm{Y}_{12}$ receptor antagonist (prasugrel, ticagrelor, elinogrel and cangrelor) have advantages over clopidogrel, including more rapid, more complete inhibition of platelet function and less variable. Recent clinical studies for ticagrelor demonstrate that these new $\mathrm{P}_{2} \mathrm{Y}_{12}$ receptor antagonists have more rapid antithrombotic effects than clopidogrel, without an unacceptable bleeding risk or other side effects [42]. Further clinical studies are still ongoing. GPIIb/IIIa antagonists, such as abciximab, are mainly used in high-risk patients before PCI; however, it is associated with bleeding risks in dose-dependent manner. Many other novel antiplatelet agents (e.g. antagonists of vWF, PAR-1, GPVI, and novel integrin $\alpha \mathrm{IIb} \beta 3$ epitopes) are in development as antithrombotic agents. Among them, blocking the interaction between vWF and GPIb, which mainly occurs under high shear stress in arterioles, is recently suggested to be an alternative promising target due to fewer bleeding complications. Here, we highlight that the future goal for antiplatelet therapy should try to achieve an optimal balance between antithrombotic efficacy and bleeding risk.

Another fundamental question is so far known antiplatelet mechanisms aim at preventing platelet adhesion, activation and aggregation rather than the more clinically relevant issue of resolution of an existing thrombus, highlighting a pressing clinical need for better therapeutic approaches. Interestingly, recent studies pointed to an additional mechanism via platelet GPIIIa49-66 ligands that binds to platelet GPIIIa49-66 epitope that is aimed at disintegrating already formed platelet aggregates $[84,85]$. These agents are unique in that it has no effect on platelet function and minimal effect on platelet count $(<15 \%)$ [85]. They dissolve already-formed platelet thrombi by binding to activated platelets within the platelet thrombus as well as to activated early platelet deposition on post ischemic endothelial cells[86]. These therapeutic agents are, therefore, safer as well as more efficient than conventional antiplatelet agent that block platelet function and induce thrombocytopenia and mortality. Thus, GPIIIa49-66 ligand-induced platelet fragmentation may represent a new direction for thrombosis therapy.

\section{References}

1. Davì G, Patrono C (2007) Platelet activation and atherothrombosis. N Engl J Med 357: 2482-2494.

2. Sadler JE (2002) Biomedicine. Contact--how platelets touch von Willebrand factor. Science 297: 1128-1129.

3. Raju NC, Eikelboom JW, Hirsh J (2008) Platelet ADP-receptor antagonists for cardiovascular disease: past, present and future. Nat Clin Pract Cardiovasc Med 5: 766-780.

4. Monroe DM, Hoffman M, Roberts HR (2002) Platelets and thrombin generation Arterioscler Thromb Vasc Biol 22: 1381-1389.

5. Stoll G, Kleinschnitz C, Nieswandt B (2008) Molecular mechanisms of thrombus formation in ischemic stroke: novel insights and targets for treatment. Blood 112: 3555-3562.

6. Varga-Szabo D, Pleines I, Nieswandt B (2008) Cell adhesion mechanisms in platelets. Arterioscler Thromb Vasc Biol 28: 403-412.

7. Nesbitt WS, Westein E, Tovar-Lopez FJ, Tolouei E, Mitchell A, et al. (2009) A shear gradient-dependent platelet aggregation mechanism drives thrombus formation. Nat Med 15: 665-673.

8. Michelson AD (2010) Antiplatelet therapies for the treatment of cardiovascular disease. Nat Rev Drug Discov 9: 154-169.

9. Keefe AD, Schaub RG (2008) Aptamers as candidate therapeutics for cardiovascular indications. Curr Opin Pharmacol 8: 147-152.

10. Bouchard PR, Hutabarat RM, Thompson KM (2010) Discovery and development of therapeutic aptamers. Annu Rev Pharmacol Toxicol 50: 237-257.

11. Diener JL, Daniel Lagassé HA, Duerschmied D, Merhi Y, Tanguay JF, et al (2009) Inhibition of von Willebrand factor-mediated platelet activation and thrombosis by the anti-von Willebrand factor A1-domain aptamer ARC1779. J Thromb Haemost 7: 1155-1162.

12. Arzamendi D, Dandachli F, Théorêt JF, Ducrocq G, Chan M, et al. (2011) An anti-von Willebrand factor aptamer reduces platelet adhesion among patients receiving aspirin and clopidogrel in an ex vivo shear-induced arterial thrombosis. Clin Appl Thromb Hemost 17: E70-E78.

13. Knöbl P, Jilma B, Gilbert JC, Hutabarat RM, Wagner PG, et al. (2009) Anti-von Willebrand factor aptamer ARC1779 for refractory thrombotic thrombocytopenic purpura. Transfusion 49: 2181-2185.

14. Kageyama S, Yamamoto $H$, Nakazawa $H$, Matsushita J, Kouyama T, et al. (2002) Pharmacokinetics and pharmacodynamics of AJW200, a humanized monoclonal antibody to von Willebrand factor, in monkeys. Arterioscler Thromb Vasc Biol 22: 187-192.

15. Vanhoorelbeke K, Depraetere H, Romijn RA, Huizinga EG, De Maeyer M et al. (2003) A consensus tetrapeptide selected by phage display adopts the conformation of a dominant discontinuous epitope of a monoclonal anti-VWF antibody that inhibits the von Willebrand factor-collagen interaction. J Biol Chem 278: 37815-37821.

16. De Meyer SF, Staelens S, Badenhorst PN, Pieters H, Lamprecht S, et al. (2007) Coronary artery in-stent stenosis persists despite inhibition of the von Willebrand factor--collagen interaction in baboons. Thromb Haemost 98: 1343-1349.

17. Siller-Matula JM, Merhi Y, Tanguay JF, Duerschmied D, Wagner DD, et al (2012) ARC15105 is a potent antagonist of von Willebrand factor mediated platelet activation and adhesion. Arterioscler Thromb Vasc Biol 32: 902-909.

18. Bartunek J, Barbato E, Heyndrickx G, Vanderheyden M, Wijns W, et al. (2013) Novel antiplatelet agents: ALX-0081, a Nanobody directed towards von Willebrand factor. J Cardiovasc Transl Res 6: 355-363.

19. Fontayne A, Meiring M, Lamprecht S, Roodt J, Demarsin E, et al. (2008) The humanized anti-glycoprotein Ib monoclonal antibody h6B4-Fab is a potent and safe antithrombotic in a high shear arterial thrombosis model in baboons. Thromb Haemost 100: 670-677.

20. Hennan JK, Swillo RE, Morgan GA, Leik CE, Brooks JM, et al. (2006) 
Pharmacologic inhibition of platelet VWF-GPIb alpha interaction prevents coronary artery thrombosis. Thromb Haemost 95: 469-475.

21. Yang J, Ji S, Dong N, Zhao Y, Ruan C (2010) Engineering and characterization of a chimeric anti-platelet glycoprotein Ibalpha monoclonal antibody and preparation of its Fab fragment. Hybridoma (Larchmt) 29: 125-132.

22. Massberg S, Konrad I, Bültmann A, Schulz C, Münch G, et al. (2004) Soluble glycoprotein VI dimer inhibits platelet adhesion and aggregation to the injured vessel wall in vivo. FASEB J 18: 397-399.

23. Schulz C, Penz S, Hoffmann C, Langer H, Gillitzer A, et al. (2008) Platelet GPVI binds to collagenous structures in the core region of human atheromatous plaque and is critical for atheroprogression in vivo. Basic Res Cardiol 103: 356-367.

24. Gibbins JM, Okuma M, Farndale R, Barnes M, Watson SP (1997) Glycoprotein $\mathrm{VI}$ is the collagen receptor in platelets which underlies tyrosine phosphorylation of the Fc receptor gamma-chain. FEBS Lett 413: 255-259.

25. Ungerer M, Rosport K, Bültmann A, Piechatzek R, Uhland K, et al. (2011) Novel Antiplatelet Drug Revacept (Dimeric Glycoprotein VI-Fc) Specifically and Efficiently Inhibited Collagen-Induced Platelet Aggregation Without Affecting General Hemostasis in Humans Clinical Perspective. Circulation 123: 1891-1899.

26. Zafar MU, Ibáñez B, Choi BG, Vorchheimer DA, Piñero A, et al. (2010) A new oral antiplatelet agent with potent antithrombotic properties: comparison of DZ-697b with clopidogrel a randomised phase I study. Thromb Haemost 103: 205-212

27. Michelson AD (2008) P2Y12 antagonism: promises and challenges. Arterioscler Thromb Vasc Biol 28: s33-38.

28. Cattaneo M (2007) Platelets. Michelson AD (ed.). (2ndedn), Elserier/Academic press, San Diego 1127-1144.

29. Bertrand ME, Rupprecht HJ, Urban P, Gershlick AH; CLASSICS Investigators (2000) Double-blind study of the safety of clopidogrel with and without a loading dose in combination with aspirin compared with ticlopidine in combination with aspirin after coronary stenting : the clopidogrel aspirin stent international cooperative study (CLASSICS). Circulation 102: 624-629.

30. Quinn MJ, Fitzgerald DJ (1999) Ticlopidine and clopidogrel. Circulation 100: 1667-1672.

31. Antithrombotic Trialists' Collaboration (2002) Collaborative meta-analysis of randomised trials of antiplatelet therapy for prevention of death, myocardial infarction, and stroke in high risk patients. BMJ 324: 71-86.

32. Yusuf S, Zhao F, Mehta SR, Chrolavicius S, Tognoni G, et al. (2001) Effects of clopidogrel in addition to aspirin in patients with acute coronary syndromes without ST-segment elevation. N Engl J Med 345: 494-502.

33. Michelson AD, Frelinger AL, Furman MI (2006) Resistance to antiplatelet drugs. Eur Heart J 8: G53.

34. Snoep JD, Hovens MM, Eikenboom JC, van der Bom JG, Jukema JW, et al (2007) Clopidogrel nonresponsiveness in patients undergoing percutaneous coronary intervention with stenting: a systematic review and meta-analysis. Am Heart J 154: 221-231.

35. Sugidachi A, Asai $F$, Ogawa T, Inoue T, Koike $H(2000)$ The in vivo pharmacological profile of CS-747, a novel antiplatelet agent with platelet ADP receptor antagonist properties. Br J Pharmacol 129: 1439-1446.

36. Brandt JT, Payne CD, Wiviott SD, Weerakkody G, Farid NA, et al. (2007) A comparison of prasugrel and clopidogrel loading doses on platelet function: magnitude of platelet inhibition is related to active metabolite formation. Am Heart J 153: 66.

37. Montalescot G, Wiviott SD, Braunwald E, Murphy SA, Gibson CM, et al. (2009) Prasugrel compared with clopidogrel in patients undergoing percutaneous coronary intervention for ST-elevation myocardial infarction (TRITON-TIMI 38): double-blind, randomised controlled trial. Lancet 373: 723-731.

38. Wiviott SD, Braunwald E, McCabe CH, Montalescot G, Ruzyllo W, et al. (2007) Prasugrel versus clopidogrel in patients with acute coronary syndromes. N Engl J Med 357: 2001-2015.

39. van Giezen JJ, Humphries RG (2005) Preclinical and clinical studies with selective reversible direct P2Y12 antagonists. Semin Thromb Hemost 31: 195-204.

40. Storey RF, Angiolillo DJ, Patil SB, Desai B, Ecob R, et al. (2010) Inhibitory effects of ticagrelor compared with clopidogrel on platelet function in patients with acute coronary syndromes: the PLATO (PLATelet inhibition and patient Outcomes) PLATELET substudy. J Am Coll Cardiol 56: 1456-1462.
41. Gaglia MA Jr, Waksman R (2011) Overview of the 2010 Food and Drug Administration Cardiovascular and Renal Drugs Advisory Committee meeting regarding ticagrelor. Circulation 123: 451-456.

42. Wallentin L, Becker RC, Budaj A, Cannon CP, Emanuelsson H, et al. (2009) Ticagrelor versus clopidogrel in patients with acute coronary syndromes. $\mathrm{N}$ Engl J Med 361: 1045-1057.

43. Gurbel PA, Bliden KP, Antonino MJ, Stephens G, Gretler DD, et al. (2010) The effect of elinogrel on high platelet reactivity during dual antiplatelet therapy and the relation to $\mathrm{CYP} 2 \mathrm{C} 19^{\star} 2$ genotype: first experience in patients. $\mathrm{J}$ Thromb Haemost 8: 43-53.

44. Bhatt DL, Lincoff AM, Gibson CM, Stone GW, McNulty S, et al. (2009) Intravenous platelet blockade with cangrelor during $\mathrm{PCl}$. N Engl J Med 361 2330-2341.

45. Harrington RA, Stone GW, McNulty S, White HD, Lincoff AM, et al. (2009) Platelet inhibition with cangrelor in patients undergoing PCI. N Engl J Med 361: 2318-2329.

46. Wang YX, Vincelette J, da Cunha V, Martin-McNulty B, Mallari C, et al. (2007) A novel P2Y(12) adenosine diphosphate receptor antagonist that inhibits platelet aggregation and thrombus formation in rat and dog models. Thromb Haemost 97: 847-855

47. Post JM, Alexander S, Wang YX, Vincelette J, Vergona R, et al. (2008) Nove $\mathrm{P} 2 \mathrm{Y} 12$ adenosine diphosphate receptor antagonists for inhibition of platelet aggregation (II): pharmacodynamic and pharmacokinetic characterization. Thromb Res 122: 533-540

48. Andrews RK, Gardiner EE, Shen Y, Berndt MC (2004) Platelet interactions in thrombosis. IUBMB Life 56: 13-18.

49. Giannarelli C, Zafar MU, Badimon JJ (2010) Prostanoid and TP-receptors in atherothrombosis: is there a role for their antagonism? Thromb Haemost 104 949-954.

50. Patrono C (1994) Aspirin as an antiplatelet drug. N Engl J Med 330: 1287-1294

51. Husted S (2007) New developments in oral antiplatelet therapy. Eur Heart J Suppl 9(suppl D): D20.

52. Maalej N, Osman HE, Shanmuganayagam D, Shebuski RJ, Folts JD (2005) Antithrombotic properties of the thromboxane A2/prostaglandin $\mathrm{H} 2$ receptor antagonist S18886 on prevention of platelet-dependent cyclic flow reductions in dogs. J Cardiovasc Pharmacol 45: 389-395.

53. Vilahur G, Casaní L, Badimon L (2007) A thromboxane A2/prostaglandin H2 receptor antagonist (S18886) shows high antithrombotic efficacy in an experimental model of stent-induced thrombosis. Thromb Haemost 98: 662-669.

54. Gaussem P, Reny JL, Thalamas C, Chatelain N, Kroumova M, et al. (2005) The specific thromboxane receptor antagonist S18886: pharmacokinetic and pharmacodynamic studies. J Thromb Haemost 3: 1437-1445.

55. Bousser MG, Amarenco P, Chamorro A, Fisher M, Ford I, et al. (2011) Terutroban versus aspirin in patients with cerebral ischaemic events (PERFORM): a randomised, double-blind, parallel-group trial. Lancet 377: 2013-2022.

56. Tanaka T, Fukuta Y, Higashino R, Sato R, Nomura Y, et al. (1998) Antiplatelet effect of Z-335, a new orally active and long-lasting thromboxane receptor antagonist. Eur J Pharmacol 357: 53-60.

57. Matsuno H, Uematsu T, Niwa M, Kozawa O, Nagashima S, et al. (2002) Pharmacokinetic and pharmacodynamic properties of a new thromboxane receptor antagonist (Z-335) after single and multiple oral administrations to healthy volunteers. J Clin Pharmacol 42: 782-790.

58. Cyrus T, Yao Y, Ding T, Dogné JM, Praticò D (2007) A novel thromboxane receptor antagonist and synthase inhibitor, BM-573, reduces development and progression of atherosclerosis in LDL receptor deficient mice. Eur J Pharmacol 561: 105-111.

59. Tchana-Sato V, Dogné JM, Lambermont B, Ghuysen A, Magis D, et al. (2005) Effects of BM-573, a thromboxane A2 modulator on systemic hemodynamics perturbations induced by $\mathrm{U}-46619$ in the pig. Prostaglandins Other Lipid Mediat 78: 82-95

60. Glenn JR, White AE, lyu D, Heptinstall S (2012) PGE(2) reverses G(s)mediated inhibition of platelet aggregation by interaction with EP3 receptors, but adds to non-G(s)-mediated inhibition of platelet aggregation by interaction with EP4 receptors. Platelets 23: 344-351. 
61. Iyú D, Glenn JR, White AE, Fox SC, Dovlatova N, et al. (2011) P2Y12 and EP3 antagonists promote the inhibitory effects of natural modulators of platelet aggregation that act via cAMP. Platelets 22: 504-515.

62. Bender AT, Beavo JA (2006) Cyclic nucleotide phosphodiesterases: molecular regulation to clinical use. Pharmacol Rev 58: 488-520.

63. Barrett NE, Holbrook L, Jones S, Kaiser WJ, Moraes LA, et al. (2008) Future innovations in anti-platelet therapies. Br J Pharmacol 154: 918-939.

64. Aktas B, Utz A, Hoenig-Liedl P, Walter U, Geiger J (2003) Dipyridamole enhances NO/cGMP-mediated vasodilator-stimulated phosphoprotein phosphorylation and signaling in human platelets: in vitro and in vivolex vivo studies. Stroke 34: 764-769.

65. ESPRIT Study Group, Halkes PH, van Gijn J, Kappelle LJ, Koudstaal PJ, et al. (2006) Aspirin plus dipyridamole versus aspirin alone after cerebral ischaemia of arterial origin (ESPRIT): randomised controlled trial. Lancet 367: 1665-1673.

66. Sacco RL, Diener HC, Yusuf S, Cotton D, Ounpuu S, et al. (2008) Aspirin and extended-release dipyridamole versus clopidogrel for recurrent stroke. $\mathrm{N}$ Engl J Med 359: 1238-1251.

67. Suh JW, Lee SP, Park KW, Lee HY, Kang HJ, et al. (2011) Multicenter randomized trial evaluating the efficacy of cilostazol on ischemic vascular complications after drug-eluting stent implantation for coronary heart disease: results of the CILON-T (influence of CILostazol-based triple antiplatelet therapy $\mathrm{ON}$ ischemic complication after drug-eluting stent implantation) trial. J Am Coll Cardiol 57: 280-289.

68. Bhatt DL, Topol EJ (2003) Scientific and therapeutic advances in antiplatelet therapy. Nat Rev Drug Discov 2: 15-28.

69. Morrow DA, Scirica BM, Fox KA, Berman G, Strony J, et al. (2009) Evaluation of a novel antiplatelet agent for secondary prevention in patients with a history of atherosclerotic disease: design and rationale for the Thrombin-Receptor Antagonist in Secondary Prevention of Atherothrombotic Ischemic Events (TRA 2 degrees P)-TIMI 50 trial. Am Heart J 158: 335-341.

70. Kogushi M, Matsuoka T, Kawata T, Kuramochi H, Kawaguchi S, et al. (2011) The novel and orally active thrombin receptor antagonist E5555 (Atopaxar) inhibits arterial thrombosis without affecting bleeding time in guinea pigs. Eur $\mathrm{J}$ Pharmacol 657: 131-137.

71. Van de Werf $F$ (2011) Inhibitors of the platelet thrombin receptor: will they live up to their promises? Circulation 123: 1833-1835.

72. O'Donoghue ML, Bhatt DL, Wiviott SD, Goodman SG, Fitzgerald DJ, et al. (2011) Safety and tolerability of atopaxar in the treatment of patients with acute coronary syndromes: the lessons from antagonizing the cellular effects of Thrombin-Acute Coronary Syndromes Trial. Circulation 123: 1843-1853.

73. Wiviott SD, Flather MD, O’Donoghue ML, Goto S, Fitzgerald DJ, et al. (2011)
Randomized trial of atopaxar in the treatment of patients with coronary artery disease: the lessons from antagonizing the cellular effect of Thrombin-Coronary Artery Disease Trial. Circulation 123: 1854-1863.

74. Chintala M, Shimizu K, Ogawa M, Yamaguchi H, Doi M, et al. (2008) Basic and translational research on proteinase-activated receptors: antagonism of the proteinase-activated receptor 1 for thrombin, a novel approach to antiplatelet therapy for atherothrombotic disease. J Pharmacol Sci 108: 433-438.

75. Kristensen SD, Würtz M, Grove EL, De Caterina R, Huber K, et al. (2012) Contemporary use of glycoprotein Ilb/llla inhibitors. Thromb Haemost 107: 215-224.

76. Patrono C, Andreotti F, Arnesen H, Badimon L, Baigent C, et al. (2011) Antiplatelet agents for the treatment and prevention of atherothrombosis. Eur Heart J 32: 2922-2932.

77. Casserly IP, Topol EJ (2002) Glycoprotein Ilb/Illa antagonists--from bench to practice. Cell Mol Life Sci 59: 478-500.

78. Vergara-Jimenez J, Tricoci $P$ (2010) Safety and efficacy of abciximab as an adjunct to percutaneous coronary intervention. Vasc Health Risk Manag 6: 39-45.

79. Dery JP, O'Shea JC, Tcheng JE (2002) Eptifibatide in percutaneous coronary intervention. A review. Minerva Cardioangiol 50: 531-546.

80. Giugliano RP, White JA, Bode C, Armstrong PW, Montalescot G, et al. (2009) Early versus delayed, provisional eptifibatide in acute coronary syndromes. $\mathrm{N}$ Engl J Med 360: 2176-2190.

81. Cannon CP, Weintraub WS, Demopoulos LA, Vicari R, Frey MJ, et al. (2001) Comparison of early invasive and conservative strategies in patients with unstable coronary syndromes treated with the glycoprotein Ilb/llla inhibitor tirofiban. N Engl J Med 344: 1879-1887.

82. Scarborough RM, Kleiman NS, Phillips DR (1999) Platelet glycoprotein IIb/Illa antagonists. What are the relevant issues concerning their pharmacology and clinical use? Circulation 100: 437-444.

83. Jing BB, Li YX, Zhang H, Ren ST, Wang M, et al. (2011) Antithrombotic activity of Z4A5, a new platelet glycoprotein Ilb/Illa receptor antagonist evaluated in a rabbit arteriovenous shunt thrombosis model. Thromb Res 128: 463-469.

84. Li Z, Nardi MA, Li YS, Zhang W, Pan R, et al. (2009) C-terminal ADAMTS-18 fragment induces oxidative platelet fragmentation, dissolves platelet aggregates, and protects against carotid artery occlusion and cerebral stroke. Blood 113: 6051-6060.

85. Zhang W, Li YS, Nardi MA, Dang S, Yang J, et al. (2010) Dissolution of arterial platelet thrombi in vivo with a bifunctional platelet GPIIla49-66 ligand which specifically targets the platelet thrombus. Blood 116: 2336-2344.

86. (1997) Randomised placebo-controlled trial of effect of eptifibatide on complications of percutaneous coronary intervention: IMPACT-II. Integrilin to Minimise Platelet Aggregation and Coronary Thrombosis-II. Lancet 349: 1422-1428. 